\title{
WHEEZE ASSOCIATED RESPIRATORY SYNCYTIAL VIRUS INFECTION AND ITS PREVENTION
}

\author{
Thaplial $\mathbf{A}^{1}$, Ramachandran $\mathbf{U}^{1}$
}

\section{ABSTRACT}

\begin{abstract}
Wheeze associated respiratory infection is an important cause of morbidity and mortality in both the developed and the developing worlds. The commonest causative agent is the Respiratory Syncytial Virus (RSV). Lower respiratory infection with this virus is assuming great proportions and hence much work is being done to find a cure or at least a suitable vaccine that will be available to everyone even in the poorer countries. This article reviews the latest literature and attempts to set out some guidelines to help inreduction of the problems associated with lower respiratory infection caused by RSV in developing countries.
\end{abstract}

\section{Key Words : Lower respiratory infection, Respiratory Syncytial Virus.}

\section{INTRODUCTION}

Viral respiratory infections are a global phenomenon affecting people from every walk of life, rich and poor alike. Children in the age group of 2 months - 6 years are most prone to this illness incapacitating them from attending school regularly. It is an added problem in the developing countries due to uncongenial environmental conditions like overcrowding, overpopulation, improper housing facilities and a lack of substantial medical care. The low per capita income in these underprivileged areas make the parents unable to afford costly hospitalization.
Virus infections other than smallpox and hepesvirus have been extensively studied in the last two centuries. Acute Lower Respiratory Infections (ALRI) which occur in children are predominantly viral in nature barring a few of bacterial aetiology, namely Streptococcus pneumoniae, Hemophilus influenzae and Staphylococcus aurous. Respiratory Syncitial Virus (RSV) is the most common viral cause of ALRI in both the developed and developing countries.

\section{EPIDEMIOLOGY}

RSV is a single strand RNA virus belonging to the family of 'Paramyxoviridae'. It is a pneumovirus

1. Department of Paediatrics, MCOMS, Pokhara

Address for correspondence : $\quad$ Dr. A. Thaplial, Department of Paediatrics, MCOMS, Pokhara, Nepal. 
with genome size $(\mathrm{kb})$ 16-20, has a lipid bilayer envelope from which several surface proteins project and with a helical capsid symmetry. Among the surface proteins the most important is the transmembrane glycoprotein ' $F$ ' which facilitates viral entry into host cells. It stimulates cell to cell fusion ultimately forming a 'syncytium' in the cells. RSV destroys the epithelial cells of the respiratory tract by forming 'syncytia' and hence the name.

Epidemics are annual and occur in late fall, winter or in spring and last up to 5-6 months. Peak attacks in children are seen in infants in the age group of 2-4 months. In hospital admissions for respiratory illnesses, RSV accounts for 20-25\% of cases of Pneumonia and $75 \%$ of cases of Bronchiolitis in the pediatric age group. In older children the infection is milder than in infancy. Transmission is by close contact with contaminated fingers or fomites and by self- inoculation of the anterior nares or conjunctiva. Droplet infection is another method of spread. Incubation period is about 4-6 days. Viral shedding may be present for 2-3 weeks in children and for a shorter period in adults. To diagnose RSV infection one should

a) have a high index of suspicion by knowing the epidemiology of community infection

b) isolation of the virus from respiratory secretions like sputum, throat swab and nasopharyngeal swab

c) ELISA

d) immunofluorescence technique of nasal scrapings

e) complement fixation antibody technique

\section{MORBIDITY AND MORTALITY}

Around 3.7 million deaths occur from acute respiratory infections in under-fives annually: of which 3 million are due to ALRI. ${ }^{2}$ Mortality rate in children admitted to hospital with RSV is low in developed countries; yet a considerable number of children with low birth weight get repeated wheeze associated respiratory infections. ${ }^{3}$ On the other hand ALRI is one of the major causes of morbidity and death in the third world assuming huge proportions and is responsible for $20-25 \%$ of all infant deaths. RSV being the major pathogen, the link between acute infantile RSV infection and subsequent respiratory tract pathology in older children is ill understood. Increased RSV hospitalization and deaths have been attributed to certain risk factors like congenital heart disease, chronic lung disease and immuno-compromised state, especially in the developed world. ${ }^{4,5,6} 50-70 \%$ of infants are supposed to develop RSV infection in the first year of life and virtually all by the third year, either primary infection or re-infection. Unlike many other viral infections, RSV infection does not give rise to prolonged immunity and seasonal re-infection is very common.

\section{REVIEW OF LITERATURE}

Sims et al $^{7}$ in a controlled study, published an article in 1978 illustrating a very disturbing fact that severe RSV lower respiratory infection (LRI) in the first two years of life were associated with subsequent recurrent wheezing in childhood. These workers have taken inspiration from an earlier article published in 1959 by Wittig and Glaser ${ }^{8}$ about relationship between acute bronchiolitis and childhood asthma. For the next twenty years or so no substantial study was done to add to this very intriguing revelation. Children by and large experience one or more attack of RSV infection by 2-3 years of age and report for treatment of wheeze in the pre-school period.

Martinez et $\mathrm{al}^{9}$ and Pullan and Hey, ${ }^{10}$ in their study established that frequent viral LRI in the age group 0-3 years is mainly due to diminished lung function (in relation to airway size and length) early in life and such babies have a tendency to wheeze 
subsequently. This could be a transient wheeze for about 5-7 years. On the other hand a child who continues to have a persistent wheeze as asthma could have normal lung function. ${ }^{11}$ The first group of children with transient wheeze has no history of atopy, asthma and has normal IgE: whereas the second group with persistent wheeze has a positive history of allergy, asthma and elevated IgE levels.

Development of the airway tract in the fetus is completed before birth and is influenced by prenatal factors such as young maternal age, low socioeconomic strata and prematurity. Maternal smoking too has a deleterious effect on pulmonary functions in the infant ${ }^{12}$ Barker et al ${ }^{13}$ suggested a close relationship between low birth weight per se and development of bronchiolitis and pneumonia later and they could even develop chronic obstructive lung disease in adolescence and adulthood. Weber et $\mathrm{al}^{14}$ in their study in Gambia suggested that children with RSV LRI in early life had a higher incidence of transient wheeze associated symptoms for the next three years or so and the periodicity comes down with advancing age. However this study did not correlate birth weight, gestational age and maternal smoking as additional factors in the etiology of acute RSV LRI. Maternal smoking in pregnancy is the largest population-attributable factor for intra-uterine growth retardation in the developed countries. Other prenatal factors are more prevalent in the developing world.

Many queries were raised and theories postulated as to the etio-pathology of acute wheeze syndrome:

1) Is RSV LRI a predisposing factor or a marker causing atopic asthma. ${ }^{15,8}$

2) Are children with a family history of atopy more prone to severe RSV LRI and subsequent wheezing ${ }^{11}$ or not. ${ }^{16}$

3) Is RSV itself responsible for causing abnormal airway reactivity by damaging the airway ${ }^{17}$
4) Does RSV induce an atypical immune response with an imbalance of $\mathrm{TH}-1$ and $\mathrm{TH}-$ 2 cells and therefore induce asthma. ${ }^{18}$

Whatever may be the etiological factor the most important sequelae of severe RSV infection is an increased susceptibility to wheeze associated LRI in me pre-school period. Hence increased morbidity due to LRI could be prevented by an anti-RSV vaccine, the benefit of which both in health and economics may be substantial. This would definitely reduce further wheezy attacks that are impediments to growth and development and lead to better scholastic performance. It could reduce injudicious antibiotic usage resulting in development of resistant strains of bacteria. It would also reduce hospitalization thereby drastically cutting down the enormous medical expenditure to a poor person.

\section{PREVENTION OF RSV INFECTION}

Clinical trials using inactivated formalin treated intra-muscular RSV vaccine were undertaken in children as early as $1960 .{ }^{19}$ The recipients showed an early immune response but experienced more alarming LRI in subsequent infections and greater risk of hospitalization and deaths. Further studies with the virus itself were abandoned and attention was directed to evolve a passive immunity status. As per the recommendations of the American Academy of Pediatrics, RSV IVIG (Respigam) was licensed by the Food and Drug Administration (FDA) in the year 1996 for prevention of RSV LRI in children below 24 months of age with chronic lung disease or a history of premature birth $<35$ weeks of gestation. Two dosage schedules of RSV IVIG $-150 \mathrm{mg} / \mathrm{kg} / \mathrm{dose}$ and $750 \mathrm{mg} / \mathrm{kg} /$ dose, five infusions in total, were tried by a study of the National Institute of Allergy and Infectious Diseases (NIAID) on 2 different groups of children. In the higher dose group, there was a $62 \%$ 
reduction in incidence of further LRI. Period of hospitalization was reduced as compared to the lower dosage group. There was also a six-fold reduction in complications like otitis media in the higher dosage group. Although RSV IVIG prophylaxis showed an overall efficacy of $41 \%$ reduction in RSV infection, the disadvantages were too many. RSV IVIG benefit in congenital heart disease (CHD) was not established. Moreover such babies, immunized with RSV IVIG were found to have increased surgical mortality when subjected to cardiac surgery. ${ }^{20}$ Cyanosis in CHD worsened probably due to increase in the baseline hyperviscosity of serum. RSV IVIG requires monthly IV injections/infusions throughout the RSV season which is neither cost effective nor convenient. This paved the way for development of a more powerful and less inconvenient preventive therapy in the form of an anti -RSV monoclonal antibody namely PALIVIZUMAB.

\section{PALIVIZUMAB}

Palivizumab is a humanized monoclonal antibody directed against ' $\mathrm{F}$ ' glycoprotein of RSV—a surface protein that is highly conserved among RSV isolates. ${ }^{21}$ Humanized monoclonal antibody is a genetically engineered chimerical molecule mat grafts an antigen - recognition site derived from a mouse monoclonal antibody on to human immunoglobulin backbone. Mouse monoclonal antibody recognizes and counteracts a protective epitope of ' $F$ ' protein that promotes fusion of the viral envelope with host cell membrane during early stage of infection. Thus palivizumab is not derived from human immunoglobulin and hence safe from transmission of dangerous infectious agents. It can be given by intramuscular route, is well tolerated, is less costly and 50-100 times more potent.

A major double blind, randomized clinical trial called impact study enrolling 1502 children was done in three countries (USA, UK, Canada) in the year $1996 .{ }^{22}$ Palivizumab $15 \mathrm{mg} / \mathrm{kg} /$ dose was administered intramuscularly monthly once for five months. There was a $55 \%$ reduction in hospitalization rate of RSV related illness compared to the previous study with RSV IVIG with only $41 \%$ reduction. Maximum benefit was found in pretenn born children with or without chronic lung disease, m 1998 Palivizumab was approved for use in a targeted high-risk population.

\section{Comparative Study of Passive RSV IVIG and Palivizumab}

\begin{tabular}{|c|c|c|c|}
\hline S.N. & & RSV IVIG & PALIVIZUMAB \\
\hline 1 & Source & \begin{tabular}{|l|} 
Derived from human \\
donors screened for high \\
doses of neutralizing RSV \\
antibody (polyclonal) \\
\end{tabular} & $\begin{array}{l}\text { Humanized monoclonal } \\
\text { antibody (a pure antibody } \\
\text { in cell culture) }\end{array}$ \\
\hline 2 & $\begin{array}{l}\text { Transmission of } \\
\text { Pathogen }\end{array}$ & $\begin{array}{l}\text { Transmission of } \\
\text { unsuspected human } \\
\text { pathogen is possible }\end{array}$ & No such possibility \\
\hline 3 & $\begin{array}{l}\text { Route of } \\
\text { administration }\end{array}$ & $\begin{array}{l}\text { Needs intravenous } \\
\text { infusion }\end{array}$ & Given intramuscularly \\
\hline 4 & Potency & $\begin{array}{l}\text { Potency is less than } \\
\text { Palivizumab }\end{array}$ & $\begin{array}{l}\text { Potency } 50-100 \text { times } \\
\text { more than RSV IVIG }\end{array}$ \\
\hline 5 & $\begin{array}{l}\text { Allergic } \\
\text { reactions }\end{array}$ & $\begin{array}{l}\text { Allergic reaction to human } \\
\text { serum can take place }\end{array}$ & $\begin{array}{l}\text { Well tolerated and no } \\
\text { allergic reactions }\end{array}$ \\
\hline 6 & $\begin{array}{l}\text { Cost factor (in a } \\
3 \mathrm{~kg} \text { infant) }\end{array}$ & $\begin{array}{l}\text { RSV IVIG -5 infusions US } \\
\$ 3621\end{array}$ & 5 IM injections US\$ 2378 \\
\hline 7 & $\begin{array}{l}\text { Reduction in } \\
\text { hospitalization } \\
\text { rate }\end{array}$ & $\begin{array}{l}41 \% \text { reduction in } \\
\text { hospitalization }\end{array}$ & $\begin{array}{l}55 \% \text { reduction in } \\
\text { hospitalization }\end{array}$ \\
\hline 8 & $\begin{array}{l}\text { Interference } \\
\text { with other } \\
\text { immunization }\end{array}$ & $\begin{array}{l}\text { Measles, MMR, Varicella } \\
\text { vaccines should be delayed } \\
\text { for about } 9 \text { months after } \\
\text { the last dose }\end{array}$ & $\begin{array}{l}\text { Does not interfere with } \\
\text { other vaccine } \\
\text { administration }\end{array}$ \\
\hline
\end{tabular}

\section{RECOMMENDATIONS}

Developing countries, where $90 \%$ of the world's children are born each year, cannot afford the exorbitant cost of RSV IVIG or Palivizumab. The Alma Ata Declaration of 1978 emphasized the need for Primary health care with supportive National policies for comprehensive intersectorial health systems. National Acute Respiratory Infection (ARI) Programmes have been established in all regions of the world. 


\section{LOW COST STRATEGY FOR THE THIRD WORLD FOR PREVENTING ARI}

The following measures could be taken at home or in the community to reduce mortality and morbidity due to ALRI.

1) Isolation of close contacts: older children and adults can be encouraged to wear antipollution cloth masks during epidemics and while handling infants and children.

2) Teach mothers to recognize early danger signs like respiratory distress, stridor, grunting and chest indrawing, thereby seeking early medical aid.

3) Adequate distribution of essential drugs through health workers to start first level of treatment at home.

4) Vitamin A prophylaxis: Vit A stabilizes the structure and function of the mucosal surface, involving $\mathrm{T}$-Cell function and mucus production. Mortality and morbidity in ARI are increased in deficiency of Vit A. Single dose of 2,00,000 IU Vit A per year has been found to decrease childhood mortality by $50 \%$.

5) Counteract malnutrition and further vitamin deficiencies.

6) Encourage breast-feeding. Breast milk provides adequate Vit A through the first 6 months and even partly upto $1-11 / 2$ years.

7) Zinc supplementation: Zn normalizes the function of cells in many tissues. It can enhance a child's ability to combat disease states. Therefore zinc supplementation is more economically feasible than vaccines directed against a number of specific organisms. Researches are underway to prove me efficacy of Zinc in combating diarrhoea and pneumonia- the two major killers. The recommended daily dosage of Zinc is $2 \mathrm{mg}$ / $\mathrm{kg} /$ day.

\section{CONCLUSION}

Both Palivizumab and RSV IVIG will have a positive impact on pediatric clinical setting for years to come. Developed countries can well afford the exorbitant cost of the vaccine. Cost factor analysis shows that hospitalization charges for every visit with RSV LRI will ultimately outweigh the immunization cost. So why not to try and reduce the number of hospitalizations by at least $55 \%$. As regards developing countries like India, Nepal, Sri Lanka etc, the affluent class only can afford the vaccine. It is next to impossible to introduce this in the national immunization programme. However the future is not bleak. Continued research and advanced medical technology could bring out cheaper vaccines for the underprivileged whose RSV infection rate is much higher than in the upper strata of society. There is always a ray of hope-a silver lining to any dark cloud.

\section{ACKNOWLEDGEMENTS}

The authors wish to thank the Principal of MCOMS Pokhara, Dr JS Nagra, for kind permission to publish this paper.

\section{REFERENCES}

1. Harrison's Principles of Internal Medicine; 14th edition, Vol 2:1066-1067,1102-1103

2. Garenne M, Rousmans C, Campbell H. The magnitude of mortality from acute upper respiratory infections in children under 5 years in developing countries. World health Star Quat 1992; 45:180-191.

3. Cunningham CK, Macmillan JA, Gross SJ. Rehospitalization for respiratory illness in infants of less than 32 weeks gestation. Pediatr 1991; 88: 527-532. 
4. Mac Donald NE, Hall CB, Suffin SC, Alexson C, Harris PJ, Manning JA. Respiratory syncitial virus infection with congenital heart disease. N Engi J Med. 1982; 307: 397-400.

5. Groothuis JR, Gutierrez KM, Laurer BA. Respiratory syncitial vinus infection in children with bronchopuhnonary dysplasia. Pediatr $1998,82: 199-203.1$

6. Hall CB, PoweU KR, Mac Donald NE, Gala CL, Menegus ME, Suffin SC et al. Respiratory syncitial virus infection in children with compromised immune function. N Engi J Med. 1986; 315: 7781

7. Sims DG, Downham MAPS, Gardener PS, Webb JKG, Weightman D. Study of 8 year old children with a history of respiratory syncitial virus bronchiolitis in infancy. BMJ1978; ! : 11-14

8. Wittig HJ, Glaser J. The relationship between acute bronchiolitis and childhood asthma. JAllergy 1959; 30:19-23.

9. Martinez FD, Morgan WJ, Wright AL, Holberg CJ, Taussig IM, and the Group Health Medical Associates Personnel. Diminished lung function as a predisposing factor for wheezing respiratory illness in children. N Engi J Med. 1998; 319:11121117

10. Pullan CR, Hey EN. Wheezing, asthma and pulmonary dysfunction 10 years after infection with respiratory Syncitial virus in infancy. BMJ 1982; 284: 1665-1669

11. Martinez FD, Wright AL, Taussig IM et al. Asthma and wheezing in the first six years of life. NEngi $J$ Med. 1995; 332:133-138

12. Hanrahan JP, Tager $B$, Segal MR. The effect of maternal smoking during pregnancy on early infant lung function. An Rev Respir Dis 1992; 145:1129-1135

13. Barker DJP, Godfrey KM, Fall C, Osmond C, Winter PD, Shaheen SO. Relations of birth weight and childhood respiratory infection to adult lung function and death from chronic obstructive airway disease. BMJ 1991-; 303:671-675
14. Weber MW, Milligan P, Giadom B, et al. Respiratory illness after severe respiratory syncitial virus disease in infancy in Gambia. $J$ Pediatr 1999; 135: 683-688

15. Rooney JC, Williams $\mathrm{HE}$. The relationship between proved viral bronchiolitis and subsequent wheezing. J Pediatr 1971; 79:44-47

16. Sims DG, Gardener PS, Weightman D, Turner MN, Soothill JF. Atopy does not predispose to RSV bronchiolitis or post -bronchiolitis wheezing. BMJ 1981; 282: 2086-2088

17. Me Connochie KM, Roghmann KJ. Bronchiohtis as a possible cause of wheezing in childhood.New evidence. Paediatrics 1984; 74:1-10

18. Renzi PM, Turgeon JP, Yang JP, Drblik SP, Marcotta JE, Pedneault L, et al Cellular imunity is activated and a $\mathrm{TH}-2$ response is associated with an early wheezing in infants after bronchiolitis. J Pediatr 1997; 130: 584-593

19. Fulginit VA, EUer JJ, Sieber OF, Joyner JW, Mmamitani M, Meiklejohn G. Respiratory virus immunization. A field trial of two inactivated respiratory virus vaccines- an aqueous trivalent parainfluenza virus vaccine and an alum precipitated respiratory syncitial virus vaccine. $\mathrm{Am}$ J Epidemiol 1969; 89: 435-448

20. Simoes EAF, Sonderheimer HM, Top FH, et al. Respiratory syncitial virus imune globul in for prophylaxis against respiratory syncitial disease in infants and children with congenital heart disease. $\mathrm{J}$ Pediatr in Press

21. Johnson S, Oliver C, Prince GA et al. Development of humanized monoclonal antibody against respiratory syncitial vinus. J Infect Dis 1997; 176: 1215-1224

22. The IMpact -RSV study group. Palivizumab, a humanized respiratory syncitial virus monoclonal antibooly, reduces hospitalization from respiratory syncitial virus infection in high-risk infants. Pediatrics 1998; 102: 531-537

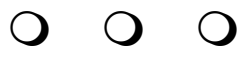

